\title{
Islamic law \& women rights in Bangladesh
}

\author{
Noor Mohammad \\ Faculty of Law, Universiti Kebangsaan Malaysia 43600, The National University of Malaysia, Bangi, Selangor Darul Ehsan
}

Email address:

noormmu2011@gmail.com (N. Mohammad)

\section{To cite this article:}

Noor Mohammad. Islamic Law \& Women Rights in Bangladesh, Social Sciences. Vol. 2, No. 2, 2013, pp. 22-33.

doi: $10.11648 /$ j.ss.20130202.11

\begin{abstract}
The concept of women rights is in fact originated from Islamic jurisprudence although there many debates and arguments on this issue. It is observed that the position of women was ignored since the pre-Islamic customs of the Arabian people in all respects. But after the revelation of the Hoy Quran, it is found that many suras such as the sura An-Nissa, Attin, Al-Mayeda etc.; cover a wide range of women rights. The Christianity, Islam, Hinduism and Communism etc.; emphasizes equal rights to men and women. However, the women rights as guaranteed to the women are not implemented properly due to unconsciousness and ignorance as to the importance of the women, lack of knowledge in Islam etc.; and therefore, the scholars of the Muslim world suggested that the respective government may pass some leading laws empowering the women community such as the Muslim Family Laws Ordinance, 1961; the Muslim Marriage and Divorce Act, 1939; the Family Laws Ordinance, 1985 etc.; which is really significant in this regard. It is being done in the most of the Islamic countries in the world including Pakistan, India, Tunisia, Saudi Arabia, Kuwait, Oman, Bahrain etc. The authority should implement the provisions of the International Bill of Human Rights as to the women rights. In Bangladesh, there are some important laws as mentioned above. This study however, examines the potentialities and constraints of the Islamic Family Laws in Bangladesh focusing on the women rights as applied in in the country based on the primary and secondary sources consisting of 25 respondents in the different criteria such as lecturers, students, primary school teachers, common people, business people, lawyers etc.; in Sylhet.
\end{abstract}

Keywords: Islamic Law, Women Rights

\section{Introduction}

All human beings are born free and equal in dignity and rights.

Universal Declaration of Human Rights, 1948.

The term 'women rights' is a very vast and vague issue. Its importance has been discussed all over the world. Many national and international seminars and symposiums are being held on this issue. Their importance has been discussed in many dimensions. It is also discussed in the different religions. The scholars of the world have also been elaborating their rights. The women rights are Islam has clearly been discussed. It is explained broadly compared to the other religions. Many poets and authors in this world including the National Poet of Bangladesh such as Kazi Nazrul Islam have composed many poems on the women's rights and he explained that they are equally important with the male. The world history also supports that the role of women bears a great significant role to the growth and development of human civilization. In fact, this theme is ori- ginated from the messages of Islam along with other religions as Islam explains it clearly. Some ideas relating to women rights are also found in the history of human rights. Particularly, some issues regarding human rights may be discussed under the Hamburabi Code (2130-2088) BC passed by the King Hamburabi [1]. Later on, it was supported by the sources of the Islamic law such as the Holy Quran, Hadith, Ijma and Qias etc. [2]. The women rights issue may be discussed as per the following documents and its implications. However, after the period of king Ibarian, the king 2nd Andrew of Hungary declared some rights to the, Ameer, Omrah and the Aristocrats. About one hundred years ago, Rud Loof Von Garing (1852-78) guaranteed some rights to the Romans. Some fundamental rights for men and women are also reflected in documents of the Magna Carta, 1215; the Petition of Rights, 1628 and the Bill of Rights, 1689; the Act of Settlement, 1701; the French Declaration of Rights of Man and of the Citizen, 1789 etc. A set of rights are also found in the declaration of the Universal Declaration of Human Rights, 1948 [3]. Moreover, some rights are also observed in the writings of different authors such as the 
Bodin, Russo, Hugo Grotius, Vetel and Blackstone etc. [4].

\section{Problem Statement}

The term 'human being' includes men and the women and their children simultaneously and in the absence of the one the other is meaningless. So discussion on the implementation of human rights on the women rights has been a matter of worldwide discussion. It is very essential for human resources development [5]. Islam has given equal importance on male and women's rights. Many institutions have been dealing with the implementation of women rights. But it is often observed that these legal institutions are not adequately developed and addressed accordingly [6]. Consequently, their efforts in the implementation of women rights are abused due to some constraints such as lack of enforcement of laws and policies etc. Moreover, the insufficient laws, unenforceability of law, ignorance of law etc., are some of them. It may be mentioned that in Bangladesh, there is not enough legal supports for ensuring women rights at the grass roots levels but they are still enjoying their rights. Though there exists some laws relating to the rights of the women but their implementation is not up to the mark. It is notable that the Government of Bangladesh did not implement all the provisions related to the International Human Rights Bill properly although there are some laws and policies in this regard [7]. The policy makers are not fully aware about the implications of the women rights. It has been a debatable issue that the laws relating to the women's rights are not framed scientifically in line with the spirit of the Shariah. In Bangladesh, the National Women Development Policy, 2008 has become a debatable issue to the nation. It needs massive discussions, seminars and symposiums for its proper and fruitful implementation. Some religions do not reflect properly the rights of the women. In the pre Islamic period, the women rights were also ignored and they were deprived of their rights frequently. In addressing this issue, the Muslim Family Courts have been working in the country wide and these courts are also still limited.

\section{Objectives}

The main objective of this study is to deal with the shariah laws and women rights. Moreover, there are two specific objectives of the study as follows:

1. To evaluate the women rights under the Islamic Jurisprudence as practiced in Bangladesh.

2. To evaluate the women rights under the national and international legal context.

\section{Methodology}

This study is based on the primary and secondary sources with regard to the women rights and empowerment based on the Muslim family laws. The primary source includes the interview session, observations, case study, focus group discussion, discussion and interpretations on the related national and international legislations as applied in Bangladesh.

The secondary source includes the relevant published and unpublished materials such as books, existing laws, journals; web based information or the internet, newspapers, magazine etc., focusing on women rights via Sharia law and the Muslim family laws of Bangladesh and abroad in relation to the International Human Rights Documents. This study consists of 25 relevant respondents in different criteria such as students, lecturers, school teachers, civil society, and ordinary people conducted in Sylhet, Bangladesh etc. The researcher gathered qualitative data pertaining to women rights through structured and unstructured questionnaire and a discussion and the results of this study have been made accordingly and observations. The study also analyzes the different relevant case laws related to the Muslim family laws in this regard. Moreover, this study has focused on the existing Islamic legal mechanisms in relation to the International Human Rights Documents available in Bangladesh.

\section{Literature Review}

Women rights and their empowerment is a global issue now a day. Their rights and duties towards the society have been discussed globally. In the meantime, some important legislation on the women empowerment has been passed by the different governments throughout the world. It is an ongoing debatable in the modern age. However, in order to draw a conceptual framework of this study, the relevant research works have been discussed as follows: Raihanah Abdullah and Begum Asma Siddiqua (2009) explained many issues on the women rights and empowerment entitled 'the Legal Reforms of the Islamic Family Law in Indian Sub-Continent'. They discussed under the position of shariah law as well as the different legislations passed by the various Islamic countries focusing on the Indian sub-continent in the world. These Islamic law scholars also discussed the evidence act, the case law from the India, Pakistan, and Bangladesh etc. [8].

Shamsuddin Ahmed (2009) discussed the position of women rights in Malaysia titled 'Women Rights in Malaysia are Balanced and Praiseworthy'. Dr. Ahmed discussed the women rights in very practical manners including Islam and human rights, rights in jobs, public forum, right to public places, praying rights, family rights, right to work, constitutional position in women rights etc [9].

Bahram Navazeni and Ms. Maryam Navazeni (2009) discussed 'the women rights in Iran'. They argued that the women rights have been discussed in their constitution, civil code and other relevant statutes and government regulations currently applying in Iran. The authors discussed the women rights under the Labour Law 1989, Military Service Law, the Family Protection Law 1974 etc. [10].

M. Mahabob Murshed (2009) discussed the women rights in Bangladesh and the role of family courts, the human rights context nationally and internationally and Islamic context in this regard [11]. 
Rushan Ara argued about the traditional controversies regarding women rights in Islam. She tried to discuss this issue in the light of the complete code of life based on the shariah law.

Shaheed Ahmed Chowdhury and Nur Muhammad Azami highlighted about the modes of dissolution of marriage under the sharia law. The authors argued that women rights are fully given in shariah law but we hardly understand the importance and inner meaning of shariah law in its application [13].

Professor Ahmad Ibrahim is one of the famous authors on the family law matters in the country. He discussed (1997) in his landmark book covering both Muslim and non-Muslim family law issues since 1997 [14]. In relation to the family matters, Jennifer Levin (1982) discussed the Islamic Marriage Issues including the Children's Rights [15]. Regarding the conversion issues, Nuraisyah Chua Abdullah (2004) broadly discussed this issue [16].

Mohammad Hashim Kamali (2000) discussed the Islamic Family Laws in Malaysia based on the sources of Islamic Law in the light of the Holy Quran as published [17].

Mohammad Hashim Kamali, Principles of Islamic Jurisprudence discussed the core concept and ideas on the Shariah Laws and principles [17].

Mahathir Mohammad, Islam the Misunderstood Religion discussed on the different aspects in Islam [18].

Muhammad Faiz-ud-Din (2009) discussed the Islamic Family Laws Issues in Bangladesh based on the statutory laws as published in 2009. It is a comprehensive and detailed book on the Islamic Family Law in Bangladesh. The author discussed it based on his teaching and research experience [19].

Syed Khalid Rashed entitled 'Muslim Law' discussed about the fundamental concepts on the Islamic Laws based on the Quran. He is a prominent author on this book. His contribution is a remarkable in this field of study [20].

Shaukat Mahmud, Principles and Digest of Muslim Law discussed the core Islamic Laws for the Muslim Ummah. It is one of the fundamental books on the Muslim Family Law Issues all over the world [21].

D.F. Mullah discussed about the Quranic principles on the Muslim Family Law Issues for the Muslim Community. This publication will bear significant role relating to my work [22].

"The Future of Shariah and the Shariah Courts in Malaysia." The Journal of Malaysian and Comparative Law.

Noor Mohammad (2010) discussed some family laws issues comparing with the Malaysian context as published in the journals as well as conference proceedings [23].

Kamala M.G. Pillai (2009) discussed various legal principles of family law including the non-Muslim. It covers the civil law aspect of family law that applies to non-Muslim citizens both in Peninsular and East Malaysia - the Chinese, Indians, Ibans, Kadazan Dusuns, Dayaks, Muruts, Bidayuhs, Orang Ulus and Bajaus. It includes domestic violence where the Domestic Violence Act 1994 is discussed covering the rights of the children under the Federal Constitution and parental child abduction. The author discusses the impact of conversion to Islam and its consequences on marriage where a spouse converts without informing the partner about it.

David C. Buxbaum (1966) discussed the development of Chinese family law in Malaysia and Singapore that provides an interesting case study of an attempt to fuse elements of two disparate legal systems in a foreign social climate. The author mentioned that the Malaysia and Singapore family law courts are almost based on the common law in its procedural law context while the substantive family law applied to the Chinese people is almost based on traditional Chinese law. It means the Chinese family law is more towards the traditional practices, culture, customs, etc [25].

Maurice Freedman (1957) discussed the Chinese family life and its regulations covering marriage, divorce, polygamy, historical background in Singapore [26].

M.B. Hooker (1969) discussed the relationship between Chinese Law and Common Law in Malaysia, Singapore and Hong Kong relating to marriage, divorce, dower, maintenance, inheritance etc [27].

Mohammad Abu Sayeed (2009) analyzed the modes of maintenance for Muslim Women under the Islamic law context.

Kaniz Fatima (2009) discussed the position of inheritance law in Islam. She pointed out that the comprehensiveness and divineness of shariah law needs to be understood. Otherwise, social problems will be created and our life will be miserable which is also supported by Shaheed Ahmed.

Maimul Ahsan Khan, an Islamic scholar and editor of the Women Rights in Islam discussed various issues on the women rights in Islam and its application in our daily life.

\section{Results and Discussion}

The Government of Bangladesh has passed some important laws relating to the women rights and empowerment in Bangladesh. The relevant issues have been discussed as follows:

\subsection{Bangladesh Context}

First of all, the role of the Family Courts Ordinance, 1985 has been discussed here pertaining to the women rights and their issues as discussed [28]. Their role is very critical on this issue as the family court possesses several jurisdictions over the family matters for Bangladesh such as the dissolution of marriage, restitution of conjugal rights, dower, maintenance, guardianship and custody of children. The Family Court will work in line with the Muslim Family Laws Ordinance, 1961 and the Muslim Marriages and Divorce Act, 1939 [29]. The divorce is one of the jurisdictions of the family court. Under the Muslim law, the unlimited power has been given to the husband. He may divorce his wife at his will in any time. No notice is required in this regard. But it is restricted by the State laws under the Muslim Family Laws Ordinance, 1961. The section 7 of this Ordinance describes that a notice should be served to the 
concerned chairman by the husband and to give a copy of the notice to be given to the wife. If he does not able to do so, he will be liable to prosecution under sub section (2) of the Ordinance. After receiving the notice, the chairman shall constitute an Arbitration Council for bringing about reconciliation between the parties. Even a talak in any forms shall not become effective unless expiring of 90 days from the date of divorce. The rights of both the parties are maintained and protected properly as per the direction of the sources of Muslim law as well as the State laws of the land. If the rights are infringed by the parties concerned or any other complicacies are arisen, the disputes may be settled for the recovery of the rights by the competent court. In fact, the rights of the husband and wife are ensured through this provision. In this regard, the Dissolution of Muslim Marriages Act, 1939 may be mentioned here; because some rights are mentioned in the provision of this Act which the wives are entitled to file suit and get decrees for the dissolution of her marriage on any one or more of the grounds [30]. It has empowered and ensured the equality of the women community in Bangladesh. The Polygamy has been restricted; because except with the previous permission in writing of the Arbitration Council the concerned husband doesn't able to marry another woman. The unfettered powers of the husband for divorce are limited here for which the wives are empowered in all respects for the recovery of their rights. Their prestige and rights are preserved. It has made their lives safe and sound. In the case of the Restitution of Conjugal Rights: When the wife disagrees to cohabit with her husband, the question of the restitution of conjugal rights is raised. If the rights of both the parties are infringed, the court may deal with the matter for the recovery of the rights. It is supported by a good number of case laws such as moonshee Buzloor Ruheem vs. Shumsoon nissa Begum (1867) 11 MIA 551; Mt. Bhawan vs. Gaman (1934)14 1461 IC 292 etc. [31]. Dower is another important jurisdiction of the court. It is given as security to the wife as per the provision of Quran. But sometimes, it is observed that the nature of dower is not specified, it may be a problem and this problem may be addressed by the court of the land [32]. The section 10 of the Muslim Family Laws Ordinance 1961 describes here that if the detail modes of dower are not specified in the nikahnama or in the contract of the marriage, the total amount of the dower shall be presumed to be payable on demand. It is noted that the right of dower of the women community has been ensured here and all sorts of confusions as to dower have also been made clear. It is supported by many case laws. In the case of inheritance, the Christianity, Islam, Hinduism and even Communism had their views. In Bible, widows and sisters don't inherit at all. Daughters can inherit only if their deceased father had no sons. Otherwise, the sons receive the entire inheritance. Among the pagan Arabs before Islam, inheritance rights were confirmed exclusively to the male relatives. The Quran abolished all these unjust customs and gave all the female relatives their just share $(4: 11,12$, and 176) of the Quran. It is true that women (daughters, sisters and mothers) do not inherit anything if a man (son) is present as per Bible. In early Palestine, the situation was different. They had to follow the British Mandate Inheritance Regulations 1923. It stipulated that females and males had equal inheritance rights. It is confirmed in the Quran that the men's responsibility is one degree above compared to women. In Iran, Shirin Ebadin, the Noble Peace Prize laureate is the popular supporter of the women's movement. But Ebadi is of the opinion that the correct interpretation of the Quran would allow equal rights to women inheritance [33]. Islam does not discriminate male and female. Maintenance is another jurisdiction of the court. The court will deal with all the matters concerning maintenance. It is added that it is not only the wife who is entitled to file a suit in a family Court for her own maintenance but also for the maintenance of her child. Their rights have been ensured. Some case laws support these norms he section 9 of the Ordinance also ensures the maintenance of the wife. The last jurisdiction of the court is the Guardianship and Custody of Children. The Court has jurisdiction to appoint a guardian of his person or property or both under Guardians and wards Act, 1890 and the Court may apply the provisions of the Majority Act, 1875. The rights of the children and its concerned are ensured and any disputes relating to the guardianship and children shall be for the purposes of recovering the rights by the courts. Some case laws are mentioned here. The rights as of the women are recognized by the provisions of The Muslim Personal Law (Shariat) Application Act, 1937. It is a matter of great regret that the Family Laws Ordinance 1985 is not applicable to the districts of Rangamati, Bandarban and khagrachari which is completely a violation for the people of those regions of Bangladesh. The government should rethink about the amendment of this law for the sake of the people. It is not only a violation to the National Laws but also the violation of the International Human Rights Documents. Some provisions are made for safeguarding the women rights by enacting the Nari-O- Shishu Nirjatan Daman (Bishesh Bidhan), Ain, 1995. It prevents all sorts of repressions to the women. This Act was amended in the year of 2000 for more effective as to the ensuring of the women and children rights. In this regard, The Acid Aparadh Daman Ain, 2002 (The Prevention of Acid Offences Act, 2002)18 is mentionable; because it safeguards for preventing the misuse of acid as corrosive substance and to provide treatment, rehabilitation and legal aid to the victim for the purpose of safeguarding and developing the women community on land. The necessary mechanisms are developed for the protection of the women of our country. The provisions of the Acid Violation Prevention Tribunal (Acid Apradh Damon Tribunal) 2002 ensure their rights. The legal Aid Act 2000 ensures the rights of the depressed, helpless people. The concerned Court will consider the provisions of the Cruelty to Women (Deterrent Punishment) Ordinance, 1983 for protecting the women rights. The dowry has been prohibited and has been made a punishable offence by the provisions of the Dowry Prohibition Act, 1980. It has kept up the prestige of the women as well as the instructions of the Holy Quran. The Muslim Marriage and Divorce (Registration Act) con- 
firms the validity of the marriages and removes a doubt on the solemnization of the marriage itself. It is supported by the section 5 of the Muslim Family Laws Ordinance, 1961. In this connection, some constitutional provisions may be discussed. The Article 27 of the constitution describes that all people including women are equal before law and are entitled to equal protection of law [34]. Nobody can have the right to infringe their rights. If the rights are infringed by any authority performing any function in connection with the affairs of the Republic, the affected party must seek the remedies to the competent courts of our country as per the Articles 102 of the constitution and no discriminate against any citizen on grounds only of religion, race, caste, sex or place of birth can be made. Relevantly, it is admitted in all hands that the judicial activism bears a leading role for addressing the violence against women in general and domestic violence particularly in the name of judicial review all over the world [34]. It is notable that the Government of Bangladesh has taken a revolutionary step for strengthening the human rights protection and has been combating violence against women and children rights. It should immediately be effective by adopting necessary arrangements for the sake of the people of Bangladesh [35]. In support of their rights, some religious values may be added. Islam recognizes and approves the various kinds of rights such as equality before law, rights relating to life, right to liberty, safety of life, chastity of women, importantly and significantly. Islam never permits any discrimination between men and women. Allah describes and reveals many suras in the Holy Quran. Under the Police Act, 1861, it is mentioned that there are some duties and responsibilities of the police community to the common people of the land. It has provisions for safeguarding the human rights of the accused with a view to giving them the benefits of a fair and impartial trial and upholding his dignity as human being.In the Prisons Act, 1894, there are some provisions where Rights of the civil and criminal prisoners are rocognisesd.36In the Penal Code, 1860 , some important provisions have been inserted for ensuring human rights to the people of the land. It bears some important provisions such as 324-331, 335, 339, 352, 355 and 358 for the protection and development of the human being. It eliminates all kinds of torture and other cruel, inhuman or degrading treatment or punishment. It bears special sections dealing with the rape, trafficking, assault, defamation and acid throwing etc. In the Labour Laws, it is found that the existing labor laws in Bangladesh are adequate but its implementation is not properly implemented due to non-coordination, British Colonial Law etc. This law provides health and safety net programs, working environment, job security, conditions of work, employment benefits, compensation, and protection of laws etc., engaged in the concerned factories or in any appropriate places. It is a hinder to the development of the women community in Bangladesh. Some provisions are also found in the Local Government Laws. The government of Bangladesh has already taken some measures such as the amendment of the Union Parishad Ordinance 1983 including legislations for ensuring the women rights in our society. The article 59 of the Constitution of Bangladesh focuses rights and duties or the responsibilities of the Representative of the Local Government of Bangladesh. The representation of the women community has been ensured in all the local government levels by amending the existing laws of the local government. The Bengal Jail Code 1894 describes the various rights of the women prisoners at jail. This code is treated as the safeguard of the women community. The life of the prisoners both male and female is regulated by the provisions set out in the jail code. The necessary security and applicability to women are maintained in this code.

The Criminal Procedure Code 1898 safeguards the arrested and detained prisoners in jail. The chapter $\mathrm{V}$ of this said code expressed the provisions of arrest in Bangladesh. The section 382 of the code, in respect of criminal offence, a woman will get some preferences than a man such a death penalty will not be applied against a woman if she is pregnant. Under the section 497, a woman even after committing a non-bailable offence may be released in bail. The Millennium Development Goals (MDG) takes some initiatives in the programs of the Millennium Development Goals as to the development and empowerment of the women's community in Bangladesh. National Women Development Policy describes some provisions for women development in Bangladesh [36]. In 1997, the government formulated National Women Development Policy in the light of CEDAW and the Policy was renewed in August 1999. The Ministry of Women and Children Affairs constituted a Committee with representation from women right groups. A CEDAW forum was set up in 1992 by women organizations to disseminate universal charter of rights of women across the country. In the Nikahnama (Marriage Document) clearly describes the favour of men. It allows them to divorce the wife in any time and even without any valid reasons. It is agreed that Rule 19 of Nikanama empowers men and deprives the women rights. In the case of introducing the Stipend:

Since 1993, the government has made cash stipend available to girls as an encouragement if they attend primary and secondary and higher secondary schools for the purposes of enhancing protection of human rights for women. It has made women an easy access of education. The Micro-Credit Policy has enabled many rural women to become economically independent. Many government and non-government organizations have been giving micro credit to the rural people particularly the women section of people. It is added that the availability of mobile telephone in villages is readily accessible to women. As a result, the rural women are more aware about their rights than they had been before.

There are some constitutional provisions that may deal with the equal rights of both the male and the female: Some important provisions are also discussed in relation to women rights. According to the Article 27 describes that all people including women are equal before law and are entitled to equal protection of law. Nobody can have the right to infringe their rights. If the rights are infringed, they must 
seek the remedies to the competent courts of our country as per the Articles 47 and 102 of the constitution and no discriminate against any citizen on grounds only of religion, race, caste, sex or place of birth can be made. In the field Judicial Activism, it is admitted in all hands that the judicial activism bears a significant role for promoting and ensuring and leading role in addressing violence against Women in general and domestic violence particularly in the name of judicial review. Lastly, the government has taken revolutionary step for strengthening human rights protection and combating violence against women and children. It should immediately be effective by adopting necessary arrangements for ensuring human rights to the people of Bangladesh.

For example, we can consider some provisions in detailed in terms of empowerment and women rights as follows:

The Dissolution of Muslim Marriages Act 1939

This Act was passed in order to empower the women community of our Indian sub-continent. It has clarified the provisions of Muslim law relating to suits for dissolution of marriage and also to remove doubts as to the effect of renunciation of Islam by a married Muslim Women on her marriage tie. This law does not purport to effect any change in Mohammedan Law but clarifies and consolidates it. This law is termed as a landmark to the development of the Muslim wives; because some provisions are made here for which the wives are entitled to file suit and get decree for the dissolution of her marriage on any one or more of the following grounds such as:

- If the whereabouts of the husband have not been known for a period of four years

- If the husband failed or has failed to provide the maintenance of the wife for a period of two years

- If the husband has taken an additional wife in contravention of the provisions of the Muslim Family Laws Ordinance, 1961

- If the husband has been sentenced to imprisonment for a period of seven years or upwards

- If the husband has failed to perform, without reasonable cause, his marital obligations for a period of (3) three years

- If the husband was impotent at the time of marriage and continues to be so

- If the husband has been insane for a period of two years or is suffering from leprosy or a virulent venereal disease

- If any women or girl has been given in marriage by her father or other guardian before she attained the age of 18 years, repudiated the marriage before attaining the age of 19 years. Provided that the marriage has not been consummated.

- If the husband treats her wife with cruelty, that is to say,habitually assaults her or makes her life miserable by cruelty of conduct even if such conduct doe not amount to physically ill-treatment, or associate with women of evil repute or leads an infamous life, or attempts to force her to lead an immoral life, or dispose of her property or prevents her exercising her legal rights over it, or obstructs her in the observance of her religious profession or practice, or
- If the husband has more wives that one, does not treat her equitably in accordance with the injunction of the Quran.

The Family Courts will deal with all the cases mentioned in the Muslim Marriages and Divorce Act and with some provisions of the Muslim Family Laws Ordinance 1961. The Court is entitled to take necessary steps in this regard.

\subsection{International Context}

In this connection, some provisions are also made in the International Bill of Human Rights where the equal rights between the male and female are ensured and emphasized. Some articles of the different covenants read as the Article 2 of the Universal Declaration of Human Rights 1948 confirms that everyone is entitled to enjoy their rights of the declaration irrespective of race, colour, sex, language religion, etc. Nobody can deprive of their rights. If the rights are violated by anyone, that should be treated as violation of this law. The Article 3 of the International Covenant on Civil and Political Rights 1966 states that the State Parties should ensure the equal rights of men and women to the enjoyment of all civil and political rights mentioned in the covenant. The preamble of this covenant states that everyone may enjoy his civil and political rights. It is supported by the Article 3 of the International Covenant on Economic, Social and Cultural Rights 1966. The International Labor Convention 1958 describes the equal opportunities of men and women. The discrimination should be eliminated in all respects. The Maternity Protection Convention 1919, the White Lead (Painting) Convention 1921, the Night Work Women Convention, 1935 and the Underground Work (Women) Convention 1935 describe the equality of opportunity and treatment for women and workers. The United Nations Scientific and Cultural Convention 1960 ascertain that the discrimination should not be tolerated in respect of education. Everyone will enjoy equal opportunities. The Convention on the Political Rights of Women 1952 ensures the political rights such as the right of voting of the women equally with the male. The Convention on the Nationality of married Women 1957 recognizes the right of nationality of married women in relevance with the Article 15 of the Universal Declaration of Human Rights 1948. The Declaration on the Elimination of Discrimination against Women 1967 ensures equality of right with men. It emphasizes for ensuring humanity to the mankind. The Declaration on the Protection of Women and Children in Emergency and armed conflict, 1974 protects and preserves the women rights as well as the children rights in all aspects. The Convention on the Elimination of All Forms of Discrimination against Women, 1979 suggests the Government to take necessary steps for formulating the legislations in order to ensure the full development and advancement of women on the basis of equality with men. It is supported by the Optional Protocol to the convention on the Elimination of discrimination Against Women 1999. The Convention Against Torture and Other Cruel, inhuman or degradation Treatment or punishment, 1984 determines for ensuring the full and equal enjoyment by women of all human rights and fundamental 
freedoms and to take effective action to prevent violations of those rights and freedoms etc. With it, some regional human rights mechanisms such as the European Convention, the American Convention etc; bears some important provisions as to the elimination of the discrimination between men and women irrespective of language, sex, religion etc. Some women rights are also recognized in the legal documents of the Commission on the Status of Women, 1967; the Convention on Consent to Marriage 1962; the declaration on the Protection of Women and Children in Emergency and Armed Conflict, 1974; the Women's Rights Conference in Beijing, 1995 and the Women Rights Conference in New York, 2000. In addition, some articles of the regional and international Organization such as the organizations of the UNO, ASEAN, SAARC, OAS etc; has been focusing for eliminating the discrimination between men and women for the purposes of ensuring the equal rights on this earth.

\subsection{Comparative Analysis}

Some important provisions under the Islamic Family Law (Federal Territory) Act, 1984 comparing with the Muslim Family Laws in Bangladesh have been discussed as follows:

- If the husband is a missing person and his movements are not identified for a period of more than one year but in Bangladesh, it is four years.

- If the husband fails to maintain his wife for a period of three months but in Bangladesh, it is two years

- If the husband has been sentenced to imprisonment for a period of three years or more but in Bangladesh, it is seven years

- If the husband fails to fulfills his marital obligations for one year but in Bangladesh, it is three years

- If the impotence was found at the time of marriage by the wife but in Bangladesh is similar and continues so

- If the insanity, leprosy, vitilago and venereal disease for two years but in Bangladesh is also the same kind.

- Unconsummated child marriage may be repudiated by the wife before attaining the age of 18 years but in Bangladesh before 19 years.

- If the Husband's habitual assault and cruelty of the Husband and his indulgence in immoral activities or attempt to force her to lead an immoral life and also violation of the wife's property rights and in Bangladesh is similar.

- We need to consider the related laws compared to Bangladesh. So far the study thinks that the other provisions prevailing in Malaysia are equally applicable to Bangladesh.

- The Islamic Family Law 1984 in Malaysia stipulates in section 83 that the mother loses her right of custody if she leads an immoral life, neglects or is cruel to the child. The National Council of Women's Organizations has proposed that the law should be amended so that the mothers and fathers should have the same rights and authority in the matter of guardianship. It may a grow conflict between them and may be violation to the spirit of the Islamic law. Fathers must work as a guardian of the whole family which is a message of Islam [37].

\subsection{The Position of Islam and the Other Religions}

Islam is a complete code of life without establishing human rights; the complete code is not possible [38]. Hazrat (sm.) had been fighting and establishing the human rights including the women rights in the world. The prophet rightly approved in writing and in orally the human rights. He fought against the discriminations throughout the life. In the very stage of the human civilization, it was found that the people of that period were much uncivilized. They were devoid of the common sense. For getting rid of the problems, Islam was revealed for ensuring the human rights in all levels. Islam emphasizes the women rights by revelation many Suras and Ayats.

Women rights in Islam

The Women rights are in fact, a part of human rights. It is a common phenomenon that human rights are the outcome of the thoughts of the Europe-America and the philosophers and revolutionists. On the basis of their steps, in the 7 th century, the Islam presented the human rights and fundamental rights for the people including women community. The prophet (sm.) formulated Madina Sanad in 622 [39]. It is the first sanad or the constitution for the Muslims where many rights are admitted for all citizens indiscriminately. Islam recognizes and approves the various kinds of rights. These rights are not suspended or abrogated. These rights are also supported by the sources of Islamic law. A few of the rights are mentioned as mentioned in the Quran needs to be implemented and realized throughout our life in this earth [40] here:

Equality before Law

In the eye of Islam, all men and women are equal before law and they are entitled to live as brotherhood.55 It is reflected to the first Article of the Universal Declaration of Human Rights, 1948. Equality means in the case of gender based discussion. Islam has directed to take proper step for ensuring the rights of the women. The law of succession, marriage, honour etc; has been ensured by the Islam for the women. In Islamic inheritance, there are 8 women out of 12 . The wife should provide hose as the husband. According to UDHR section 2 that bear relevance with the spirit of Islam. The Article 27 of the constitution of Bangladesh deals with equality before law. The articles 14 and 27 of the constitution of Indian and Pakistan also deal with equality of law respectively.

\section{Rights relating to Life}

Much importance is given to the life of men and women in Islam. In the Holy Quran, it is said that you never kill other people's life as per the Sura Nisa: 29. The Universal Declaration of Human Rights, 1948 has ensured the security of the life as per the Article56 3. It is admitted in the section 17 of the UDHR and the Article 42 of the Constitution of Bangladesh. Islam ensures the security of life through imposing ban on killing man except on reasonable grounds. As to wealth, the holy Quran states that "Don't eat up your property among yourself in vanity."

Right to Liberty 
A great significance has been made as to personal liberty of men and women in Islam. It is granted in the Madina Sanad firstly. This sanad was formulated among the peoples of the different castes, religions etc. 57 No man can be arrested or imprisoned without justice.

Safety of Life

The right to the safety of life of men and women are discussed.58 Article 22 of UDHR reads that everyone, as a member of society, has the right to social security and is entitled to realization, through effort and international cooperation and in accordance with the organization and resources of each State of the economic, social and cultural rights indispensable for his dignity and the free development of his personality.

Chastity of Women

The third important thing is that we find in the Charter of Human Rights granted by Islam is that a woman's chastity has to be respected and protected under all circumstances, whether she belongs to our own nation or to the nation of an enemy, whether we find her in the wild forest or in a conquered city; whether she is our co-religionist or belongs to some other religion or has no religion at all.

Basic Needs

Islam recognizes the opportunities of meeting up their basic economic needs, like food, shelter, clothes, education etc. equal opportunities are recognized by Islam. 60

Freedom of Life

Islam has clearly and categorically forbidden the primitive practice of capturing a free man, to make him a slave or to sell him into slavery. In this regard, there are many messages for protecting the individual's right to freedom.61

Slavery

Briefly I would like to discuss about the position and nature of slavery in Islam. Islam tried to solve the problem of the slaves that were in Arabia by encouraging the people in different ways to set their slaves free. 62

The Right to Justice

This is a very important and valuable right which Islam has given to man as a human being. It should be ensured by any means to the people of the land.63 Islam places women at the same level as men with respect to their right to property, honour, marriage etc.

Equality of Human Beings

Islam not only recognizes absolute equality between men and women irrespective of any distinction of colour, race or nationality, but makes it an important and significant principle, a reality. 64

Right to Education:

Islam ensures education to all. No limitations have been made in this regard. Islam made compulsory education to man and women. There are many suras and Ayats in this regard.65

Right to Participate in Election:

The people should have right to discuss with the administration in all respects. In fact, the democratic values are originated from this theme.

Freedom of Religion:
Every citizen has the right to exercise the religious values. No restrictions should be imposed upon the free exercise of religion. 66.

Freedom of Conscience and Conviction:

Islam recognizes the application of the freedom of conscience and conviction.

Inheritance:

Before Islam, it is found that women were deprived of their rights of inheritance. There was no social status and values of the women. But after the revelation of Islam, it is noted that Islam granted a set of rights in different aspects of her life. For example, there are 12 quranic sharers for the male and female. Of them, eight are the female sharers. Their portions are clearly defined in the Quran that cannot be compared to other religions.

Women Rights in Buddhist Law

There is no specific and separate law for the Buddhists community. But the system of Dyvek in Hindu community is prevailing in them. They are administered and regulated by the law of Hindu except the Marua community. The Principle of Hindu Law reads as: "Hindu Law applies to Jaina, Buddhists in India Sikhs expect so far as such law is varied by custom." In fact, the women rights are not recognized by their laws. The female section of people is neglected due to lack of proper legal mechanisms. That is why; their rights are not properly recognized.

Women Rights in Christian Law

The Christian Law has recognized the women's rights equally with the male rights. That's, the equal rights between the son and the daughters are admitted in all hands. They inherit their portion of the properties of the deceased as per the section 25. No specific and independent law is found for the Christian community of our sub-continent. But their rights are administered by the Succession Act, 1925 (Act 39 of 1925) in the section 23-28 (Part. 4) and 29-49 (Part. 5).

Women Rights in Jews Law:

These religions scriptures bear very important role for promoting and promotion of the human rights including the women rights. Its objectives are to serve the mankind without any interest. It enhances to lead the man kind calmly and quietly.

\section{Global Reforms}

Globally, this study finds that most of the Islamic countries in this world, they have passed several Muslim family laws due to the proper implementation of the spirits of the Islamic jurisprudence. The reformation of Muslim jurisprudence has made a revolutionary step for ensuring the rights of the Muslim Ummah including the women rights.

\section{Case Study}

In order to complete this study, an empirical study was done in Sylhet Sadar in Bangladesh. The researcher has discussed with some selected school teachers along with other relevant stakeholders regarding the women rights in 
Bangladesh. Their arguments have been made including some philosophical comments. Allah, the Almighty said that "there is a special respect or prestige over the women for the male." According to Rossoe, Philosopher said that the prestige or the honor has been hidden in the unknown environment. His nobility depends towards the love and respect to the husband. Her happiness remains in the peace of her family.According to Rabindranath Tagore: The women themselves are prime .Her supremacy does not depend on the interference upon the activities of male. Rather the opposite reaction may happen. The softness of their character, tolerance, stability may affect the possible balance of their way of life.Miss Nipa, Age: 24, Profession: Service holder (School Teacher) expressed on women's rights on 21-12-08 and replied as below: Generally, women's are neglected by birth. In our society, it is found that merriment is observed during the period of birth of a male child but this situation is not carried out during the born of a female child. From the childhood, the female child faces various kinds of problems. The parent's feels frustration if the female child is born firstly or many female children are born initially. According to Miss Mitali, Age: 24, Profession: Service holder (School Teacher) talked to her regarding the women's rights on 21-12-08 and replied as below: the Government recognized the equal rights but their rights are not properly maintained.

According to Miss Shahida, Age: 20, Profession: Service holder (School Teacher) talked to her regarding the women's rights on 21-12-08 and replied as below: A great discrimination is created in the filed of education for the sake of women's education. It is said that Public University is for the female students and the private university is for the male students. Moreover, beautiful female students are given priorities in jobs.

According to Miss Asma, Age: 22, Profession: Service holder (School Teacher) talked to her regarding the women's rights on 21-12-08 and replied as below: the females are neglected as human being. They are treated as women not as human being. Media does not play active role with the women. In family life, discrimination is found between male and female in their activities. Males are given priorities in the family activities.

According to Miss Tara, Age: 23, Profession: Service holder (School Teacher) talked to her regarding the women's rights on 21-12-08 and replied as below:

Male's are given priorities in respect of food. The likings of the women are not sincerely considered. In marriage, attractive colored women's are demanded in our society than the less colored women. According to Miss Rozi, Age: 23, Profession: Service holder (School Teacher) talked to her regarding the women's rights on 21-12-08 and replied as below: the service, salary, work etc., of the women are devalued. In fact, they do not able to make expenses independently of his salaries. The women's education is not evaluated properly. Someone may think that they do not take their education properly.

Some comments of the Female Students, the Government
Women's College Sylhet are given below: According to Aunuva Roy, 3rd Year (Hons) of Social Work: there is no opportunity for moving independently for the women. They don't go beyond the family traditions. If the educated women try to go limitations of the family, they have to face numerous problems of the society. According to Tanni, 3rd Years (Hons) of Social Work: In our society, the females or the women's are oppressed due to dowry. According to Hanna, 3rd Year, (Hons) of Social Work: Colour, figures, age, level of educational years etc., of the female are considered for marriage. The master's level female students are given preference for marriage. According to Romi, 3rd Year, (Hons) of Social Work: Women are very humiliated in our society due to family bondage. Then the females are also suffered by the discriminatory activities of the State and the Society. The females of the South Asian Countries have been facing frequently due to abduction, rape, murder and acids etc.

According to Ms. Rokeya Sultana Bulu, MA in political science expressed her alarming feelings that the majority wives are not very happy with their husbands. They are deprived of their rights due to them. They are neglected.

\section{Recommendations}

From the above study, the following recommendations have been made:

- Need to implement the existing laws relating to women empowerment.

- Need to co-ordination among the stakeholders in relation to different Ministries, department, and division etc.

- Need to build awareness building among the people and love for proper knowledge in Islam.

- To strengthen the Family Courts with the empowerment of the Courts.

- To undertake research work relating to women environment.

- Needs to implement the decisions of the Supreme Courts of Bangladesh and that of the Sub-continent along with other decisions of the Courts.

- To understand the messages of Islam relating to Women and put into practice of them in our life.

- Male and female should be treated equally in all respects and the necessary legal mechanisms are formulated and passed by the legal mechanisms. As a result, equal rights may be established.

- Some laws may be passed in the light of the Constitutional obligations for ensuring the women rights in Bangladesh.

\section{Conclusion}

From the above discussion, it is noted that the Government of Bangladesh as well as the world leaders has taken a good number of initiatives for the purposes of developing and empowering the women community on earth. But it is a matter of regret that the legal mechanisms should be more 
developed and be implemented them properly. It has been a debate that the international legal mechanisms are insufficient and it's the implementing mechanisms is also weak. The existing mechanisms are rarely implemented and therefore, the stakeholders are facing numerous problems. The authority of these concerned should realize this truth and necessary steps should be taken immediately for our own existence on this earth. The messages of the Holy Quran, Hidith, Gita, Bible etc., should be clearly understood and implemented regarding the women rights of our daily life irrespective of language, sex, religion, colour etc. The necessary measures should immediately be made in this regard as per the sources of Islamic law as well as the spirits of the common law principles including the Muslim Family laws at home and abroad.

As per the sura Huzzrat in the ayat of 13: ' $O$ ' man, you are created one male and one female. You are divided in many castes and groups and therefore, you will be able to know each other. Islam announces that all men in the world have sprung from the same parents, (Adam and Eve), and therefore, are brother and sisters and equal in their tatuts as human beings. Islam rejects all distinctions of birth, class, race, colour and language etc.

If a man kills a man therefore he kills the humanity of the people as per the Mayeda: 32.According to the Ayat 188 of Bakara, 'O' hee, believers, you do not eat other people's property illegally. In the last sermon, the Hazrat (sm.) says that your property and life are the sacred to you. The prophet says that man is the representative of the Allah (as per the sura Bakkara: 30). Al-Quran 17:33, 5:55.b It is also stated in (Hadith: Bukhari and Muslim).

Immediately after the verse of the Holy Quran which has been mentioned in connection with the right to life, God has said: "And whoever saves a life it is as though he had. Only two kinds of detention is permissible in Islam such as (i) under the Orders of the Court, ii. For the purposes of Investigation. The Holy Quran explicitly says, "No one can bear the burden of another."

Immediately after the verse of the Holy Quran which has been mentioned in connection with the right to life, God has said: "And whoever saves a life it is as though he had saved the lives of all mankind" (5:32). There can be several forms of saving man from death. A man may be ill or wounded, irrespective of his nationality, race or colour. If you know that he is in need of your help, then it is your duty that you should arrange for his treatment for disease or wound. If he is dying of starvation, then it is your duty to feed him so that he can ward off death. If he is drowning or his life is at stake, then it is your duty to save him. You will be surprised to hear that the Talmud, the religious book of the Jews, contains a verse of similar nature, but records it in altogether different form. It says: "Whoever destroyed a life of the Israelite, in the eyes of the Scripture, it is as if he destroyed the whole world. And whoever protected and saved one life of the Israelite, in the light of the Scripture, it is as if he saved the whole world." Talmud also contains the view that if a non-Israelite is drowning and you tried to save him then you are a sinner. Can it be given a name other than racialism? We regard it as our duty to save every human life, because it is thus that we have been enjoined in the Holy Quran. On the other hand, if they regard it necessary to save the life of a human being at all, it should be the life of an Israelite. As far as other people are concerned, according to this view, they do not seem to be human enough to deserve protection of their persons. In their literature the concept of 'Goyim' for which the English word 'Gentile' and the Arabic word ummi (illiterate) is used, is that they enjoy no human rights; human rights are reserved only for the children of Israel. The Quran has mentioned this belief of the Israelites and quotes the Jews saying: "There is no blame on us (for anything we may do) with regard to the unlettered folk (i.e. the ummi)" (3:75).

Speaking about the economic rights the Holy Quran enjoins upon its followers: And in their wealth there is acknowledged right for the needy and destitute. (51:19)The words of this injunction show that it is a categorical and unqualified order. Furthermore this injunction was given in Makkah where there was no Muslim society in existence and where generally the Muslims had to come in contact with the population of the disbelievers. Therefore the clear meaning of this verse is that anyone who asks for help and anyone who is suffering from deprivation has a right in the property and wealth of the Muslims; irrespective of the fact whether he belongs to this nation or to that nation, to this country or to that country, to this race or to that race. If you are in a position to help and a needy person asks you for help or if you come to know that he is in need, then it is your duty to help him. God has established his right over you, which you have to honour as a Muslim.

On this point the clear and unequivocal words of the Prophet (S) are as follows: "There are three categories of people against whom I shall myself be a plaintiff on the Day of Judgment. Of these three, one is he who enslaves a free man, then sells him and eats this money" (al-Bukhari and Ibn Majjah). The words of this Tradition of the Prophet are also general, they have not been qualified or made applicable to a particular nation, race, country or followers of a particular religion. The Europeans take great pride in claiming that they abolished slavery from the world, though they had the decency to do so only in the middle of the last century. Before this, these Western powers had been raiding Africa on a very large scale, capturing their free men, putting them in bondage and transporting them to their new colonies. The treatment which they have meted out to these unfortunate people has been worse than the treatment given to animals. The books written by the Western people themselves bear testimony to this fact.

Speaking about the economic rights the Holy Quran enjoins upon its followers: And in their wealth there is acknowledged right for the needy and destitute. (51:19)The words of this injunction show that it is a categorical and unqualified order. Furthermore this injunction was given in Makkah where there was no Muslim society in existence and where generally the Muslims had to come in contact 
with the population of the disbelievers. Therefore the clear meaning of this verse is that anyone who asks for help and anyone who is suffering from deprivation has a right in the property and wealth of the Muslims; irrespective of the fact whether he belongs to this nation or to that nation, to this country or to that country, to this race or to that race. If you are in a position to help and a needy person asks you for help or if you come to know that he is in need, then it is your duty to help him. God has established his right over you, which you have to honour as a Muslim.

The Holy Quran has laid down: "Do not let your hatred of a people incite you to aggression" (5:2). "And do not let ill-will towards any folk incite you so that you swerve from dealing justly. Be just; that is nearest to heedfulness" (5:8). Stressing this point the Quran again says: "You who believe stand steadfast before God as witness for (truth and) fairplay" (4:135). This makes the point clear that Muslims have to be just not only with ordinary human beings but even with their enemies. In other words, the justice to which Islam invites her followers is not limited only to the citizens of their own country, or the people of their own tribe, nation or race, or the Muslim community as a whole, but it is meant for all the human beings of the world. Muslims therefore, cannot be unjust to anyone. Their permanent habit and character should be such that no man should ever fear injustice at their hands, and they should treat every human being everywhere with justice and fairness.

The Almighty God has laid down in the Holy Quran: "O mankind, we have created you from a male and female." In other words all human beings are brothers to one another. They all are the descendants from one father and one mother. "And we set you up as nations and tribes so that you may be able to recognize each other" (49:13). This means that the division of human beings into nations, races, groups and tribes is for the sake of distinction, so that people of one race or tribe may meet and be acquainted with the people belonging to another race or tribe and cooperate with one another. This division of the human race is neither meant for one nation to take pride in its superiority over others nor is it meant for one nation to treat another with contempt Indeed, the noblest among you before God are the most heedful of you" (49:13). In other words the superiority of one man over another is only on the or disgrace, or regard them as a mean and degraded race and usurp their rights. "basis of God-consciousness, purity of character and high morals, and not on the basis of colour, race, language or nationality, and even this superiority based on piety and pure conduct does not justify that such people should play lord or assume airs of superiority over other human beings. Assuming airs of superiority is in itself a reprehensible vice which no God-fearing and pious man can ever dream of perpetrating. Nor does the righteous have more privileged rights over others, because this runs counter to human equality, which has been laid down in the beginning of this verse as a general principle. From the moral point of view, goodness and virtue is in all cases better than vice and evil.. This has been exemplified by the Prophet in one of his sayings thus: "No Arab has any superiority over a non-Arab, nor does a non-Arab have any superiority over an Arab. Nor does a white man have any superiority over a black man, or the black man any superiority over the white man. You are all the children of Adam, and Adam was created from clay" (al-Bayhaqi and al-Bazzaz). In this manner Islam established equality for the entire human race and struck at the very root of all distinctions based on colour, race, language or nationality. According to Islam, God has given man this right of equality as a birthright. Therefore no man should be discriminated against on the ground of the colour of his skin, his place of birth, the race or the nation in which he was born. Malcolm X, the famous leader of African Negroes in America, who had launched a bitter struggle against the white people of America in order to win civil rights for his black compatriots, when he went to perform the pilgrimage, and saw how the Muslims of Asia, Africa, Europe, America and those of different races, languages and colours of skin, were wearing one dress and were hurrying towards God's House-the Ka'bah and offering prayers standing in one row and there was no distinction of any kind between them, then he realized that this was the solution to the problem of colour and race, and not what he had been trying to seek or achieve in America so far. Today, a number of non- Muslim thinkers, who are free from blind prejudice, openly admit that no other religion or way of life has solved this problem with the same degree of success with which Islam has done so.

The Holy Quran encourages as to knowledge as "see, look, think, judge" etc.

Allah says, "Let there be no compulsion in Religion".

Law of Personal Status, 1957 (Tunisia), the Law of Personal Status, 1959 (Iraq), the Law of Personal Status, 1959 (Iraq), the Marriage and Divorce Act, 1965, the Laws of Cyprus (Turkey) etc.

\section{Acknowledgements}

I would like to express my sincere and heart felt gratitude to the Science Publishing Group, USA for their research and academic supports in publishing the book as well as the Faculty of Law, The Universiti Kebangsaan Malaysia along with other relevant stakeholders in this regard.

\section{References}

[1] L. W. King. Hammurabi's Code of Laws, available at the http://eawc.evansville.edu/anthology/hammurabi.htm on the March 30, 2013.

[2] Sources of Sharia; available at http://en.wikipedia.org/wiki/Sources_of_sharia on the March 30, 2013.

[3] The Universal Declaration of Human Rights 1948, available at http://www.un.org/en/documents/udhr/ on March 30, 2013.

[4] Reba \& Shahjahan Mondol, Manobadhikar Ain Sangbidhan, 
Islam, NGO (Human Rights Law, Constitution, Islam \& NGO) (Chittagong: Md. Shahajahan Rashid, Islamia Hat, 1999), p. 4.

[5] Mohammad, Noor. Law and Human Rights in Bangladesh: An Empirical Study; Lap Lambert Academic Publishing, Saarbrücken, Germany, June, 2012.

[6] Islam: Equality of Men and Woman in Islam, and their complementary nature to one another; available at the http://www.womeninislam.ws/en/women-right-islam_equali ty-men-women.aspx on the 30 March 2013.

[7] Afroz, Tureen, The CEDAW and the Women's Rights in Bangladesh - a promised Silver Lining Barrister; available at the http://www.worldnewsbank.com/tureen-seminar.html on the 30th March 2013.

[8] Abdullah, Raihanah and Begum Asma Siddiqua, The Legal Reforms of the Islamic Family Law in Indian Sub-Continent, The Women Rights in Islam, edited by Maimul Ahsan Khan, 2009, Dhaka, Bangladesh.

[9] Ahmed, Shamsuddin, 'Women Rights in Malaysia are Balanced and Praiseworthy', The Women Rights in Islam, edited by Maimul Ahsan Khan, 2009, Dhaka, Bangladesh.

[10] Navazeni, Bahram and Ms. Maryam Navazeni, 'The women rights in Iran' edited by Maimul Ahsan Khan, 2009, Dhaka, Bangladesh.

[11] Murshed, M. Mahabob, the women rights in Bangladesh edited by Maimul Ahsan Khan, 2009, Dhaka, Bangladesh.

[12] Ara, Rushan, The Traditional Controversies regarding women rights in Islam, edited by Maimul Ahsan Khan, 2009 Dhaka, Bangladesh.

[13] Ahmed, Shaheed, Chowdhury and Nur Muhammad Azami, 'The modes of dissolution of marriage under the sharia law, edited by Maimul Ahsan Khan, 2009, Dhaka, Bangladesh.

[14] Ibrahim, Ahmad, Family Law in Malaysia 3rd edition, Malaysian Law Journal Sdn bhd, Kualal Lumpur, 1997, p.p. 167-217.

[15] Levin, Jennifer (1982), Family law; available at the http://www.amazon.ca/Books on the 30th March 2013.

[16] Chua, Nuraisyah. Abdullah, the Family Law; available at the http://www.ranker.com/list/nuraisyah-chua-ab.

[17] Kamali, Hashim, 2000. Islamic Law in Malaysia Issues and Developments, Ilmiah Publishers, Kuala Lumpur.

[18] Dr-Mahathir-Islam-the-Misunderstood-Religion; available at the http://www.ummah.com/forum/showthread.php?55492 on the March 30, 2013.

[19] Muhammad Faiz-ud-Din (2009), A Text Book on Islamic Laws, Shams Publications, Dhaka, Bangladesh.

[20] Khalid, Syed Rashed, The'Muslim Law' available at the http://www.amazon.com/Syed-Khalid-Rashids-Muslim-Law /dp/8170121620 on the March 30, 2013.

[21] Mahmud, Shaukat, The Principles and Digest of Muslim Law, avialble at the http://catalog.hathitrust.org/Record/010451936 on the March 30, 2013.
[22] D.F. Mulla's, principles of Mahtomedi law, available at the http://www.amazon.com/D-F-Mullas-principles-Mahomeda n-law on the March 30, 2013.

[23] Mohammad, Noor, Reformations on the Malaysian Muslim Family Law: A Case Study; European Journal of Social Sciences, 2010.

[24] Pillai, Kamala M.G. (2009), Malaysian Family Law, available at the http://library.bheuu.gov.my:8080/library/FullDisplayRetriev er.jsp?0000011572 on the March 30, 2013.

[25] Buxbaum, David C. (1966), available at the http://www.amazon.com/s?ie=UTF $8 \&$ field-author $=$ Daid $\% 2$ 0C $\% 20$ Buxbaum\&page $=1 \& \mathrm{rh}=\mathrm{n} \% 3 \mathrm{~A} 283155 \% 2 \mathrm{Cp} \_27 \% 3$ ADavid\%20C\%20Buxbaum on the March 30, 2013.

[26] Freedman, Maurice (1957) discussed the Chinese family life http://openlibrary.org/sea on the March 30, 2013.

[27] M.B.Hooker (1969); available at the http://books.google.com.my on the March 30, 2013.

[28] The Role of the Family Courts Ordinance, 1985; available at the http://bdlaws.minlaw.gov.bd/pdf_part.php?id $=682$ on the March 30, 2013.

[29] The Role of the Muslim Family Laws Ordinance, 1961 http://bdlaws.minlaw.gov.bd/pdf on the March 30, 2013.

[30] The Role of the Dissolution of Muslim Marriages Act, 1939 http://www.vakilno1.com/saarclaw/pakistan/dissolution-ofmuslim-marriages-act-1939.html on the March 30, 2013.

[31] The Role of Case Laws in Bangladesh such as the Buzloor Ruheem vs. Shumsoon nissa Begum (1867) 11 MIA 551; Mt. Bhawan vs. Gaman (1934)14 1461 IC 292 etc.

[32] Nature of Dower, available at the http://www.muslim-marriage-guide.com/dower-rights.html on the March 30, 2013.

[33] Women Empowerment, available at the http://www.nobelprize.org/nobel_prizon the March 30, 2013.

[34] The Constitution of Bangladesh article 27; available at the http://www.lawyersnjurists.com/resource/articles-and-assign ment on the March 30, 2013.

[35] The Constitution of Bangladesh article 102; available at the http://www.lawthinkers.com/tag/article-102-of-bangladesh-c onstitution/on the March 30, 2013.

[36] The Millennium Development Goals (MDG); available at the http://www.un.org/millenniumgoals/ on the March 30, 2013.

[37] The Role of the Islamic Family Law (Federal Territory) Act, 1984; available at the http://www.google.on the March 30, 2013.

[38] Islam is a complete code of life; available at the http://www.barghouti.com/islam/lifecode.html on the March 30, 2013.

[39] The Charter of Madina Sanad; available at the http://www.constitution.org/cons/medina on the March 30, 2013.

[40] Sura Maeda: Ayat 3 of the Holy Quran. 